\title{
Chemical Synthesis, Characterization and Bioactivity Evaluation of Hydroxyapatite Prepared from Garden snail (Helix aspersa)
}

\section{Anjuvan Singh ${ }^{1 *}$ and K. M. Purohit ${ }^{2}$}

${ }^{1}$ Department of Biotechnology, Lovely School of Sciences, Lovely Professional University, Phagwara, India.

${ }^{2}$ Department of Chemistry, National Institute of Technology, Rourkela -769008, Orissa, India

\begin{abstract}
A novel attempt is made to convert the calcium carbonate skeleton of widely available garden snail shell (Helix aspersa) to hydroxyapatite based bioceramics. The snail shell was found to decompose within $850^{\circ} \mathrm{C}$ to all the carbonate phases. The calcined snail shells were then treated with acids followed by different chemicals in ammoniacal media maintaining proper stoichemetry to produce fine Hydroxyapatite (HAP) as filter cake with $\mathrm{Ca} / \mathrm{P}$ molar ratio of 1.67. The dried HAP powder was extremely pure with specific surface area of $15 \mathrm{~m}^{2} / \mathrm{g}$. The different characterization techniques were adopted both for calcined snail shell and HAP synthesized like X-ray Diffraction (XRD), Thermal Analysis (DTA/ TGA), Fourier Transform Infra red Spectroscopy (FTIR) and Scanning Electron Microscopy (SEM). The surface area and the particle size, of the HAP powder prepared by chemical precipitation route, were also determined by BET and Malvern particle size analyzer respectively. The synthesized powder was soaked in stimulated body fluid (SBF) medium for various periods of time in order to evaluate its bioactivity. The changes of the $\mathrm{pH}$ of SBF medium were measured. High bioactivity of prepared HAP powder due to the formation of apatite on its surface was observed.
\end{abstract}

Keywords: Snail shell; Hydroxyapatite; Calcination; $\beta$-tricalcium phosphate; Bioactivity

\section{Introduction}

Hydroxyapatite $\left[\mathrm{Ca}_{10}\left(\mathrm{PO}_{4}\right)_{6}(\mathrm{OH})_{2}\right]$ based bioceramics are successfully used as implants as it is chemically similar with the inorganic constituent of biological hard tissue [1]. It is present in bone, teeth and tendons to give these organs stability, hardness and function. On account of its chemical similarity with the biological calcified tissue it is remarkably biocompatible [2]. Due to the formation of strong bond with the hard tissue, it is widely used in orthopedics or in dental implants.

HAP is also a potential implant material due to its excellent osteoconductive properties $[3,4]$. HAP has been shown to stimulate osteoconduction and is a material that can be integrated into bone without provoking an immune reaction. The biological response to HAP implants is influenced by its properties. The application of HAP as useful biocompatible materials largely depends on the purity and morphology of the powder. HAP can be prepared by different routes like chemical precipitation, sol-gel route, combustion synthesis, plasma etc [5-10]. The purity in the final HAP powder and stoichemetry (molar ratio of $\mathrm{Ca} / \mathrm{P}=1.67$ ) can be well controlled in chemical precipitation route. The different chemical processes use precursors like $\mathrm{Ca}\left(\mathrm{NO}_{3}\right)_{2}, \mathrm{Ca}(\mathrm{OH})_{2}$ etc. as the source of Calcium[Ca] and $\left(\mathrm{NH}_{4}\right)_{2} \mathrm{HPO}_{4}, \mathrm{H}_{3} \mathrm{PO}_{4}$ etc. as the source of Phosphorus [P] during synthesis of HAP. The extremely pure HAP powder is very costly and needs high quality precursors. The most of the sources of $\mathrm{Ca}^{2+}$ contains different types and level of impurities mainly silica. Snail shell consists of $\mathrm{CaCO}_{3}$ with minor amount of $\mathrm{MgCO}_{3}$ and other matters, can be potential precursors for the production of HAP.

The composition of human bone is an inorganic/organic hybrid consisting of $70 \%$ (wt) apatitic calcium phosphates and 30\% (wt) organic (largely collagen) [11]. The apatitic calcium phosphate of bone mineral consists of carbonate, small amount of sodium, magnesium and other trace elements. The submicroscopic crystals of calcium phosphates in bone resemble the crystal structure of synthetic HAP [12].

The objective of the present paper is to synthesize pure and biocompatible HAP using snail shell as precursor following chemical precipi- tation method [13]. The powders are characterized using XRD, DTA/ TGA, FTIR, SEM and BET surface area. Hydroxyapatite prepared by precipitation route also has the feature of small size, low crystallinity and high surfacial activation which can meet different demands [14].

Keeping the above points in mind, the present study was aimed to produce and to enhance the bioactivity of stoichemetric HAP prepared from garden snail shell (Helix aspersa) and to evaluate its bioactivity in simulated body fluid.

\section{Materials and Methods}

Garden snail shells (SS) were collected and their shell covering was removed carefully. Shells were washed with tap water followed by distilled water to remove the mud, sand and other impurities. The cleaned shells were dried in the direct sunlight for 2 days. Dry and cleaned SS were calcined at $1000^{\circ} \mathrm{C}$ for 2 hours so that all organic matters and proteins escape out. The calcined SS was treated with concentrated nitric acid to convert it to $\mathrm{Ca}\left(\mathrm{NO}_{3}\right)_{2} .130 \mathrm{ml}$. of $1.63(\mathrm{~N})$ ammonical $\mathrm{Ca}\left(\mathrm{NO}_{3}\right)_{2}$ solution was added drop wise to a mixture of ammonical $\left(\mathrm{NH}_{4}\right)_{2} \mathrm{HPO}_{4}$ solution with constant stirring with the help of magnetic stirrer. The $\mathrm{pH}$ of the solution was maintained at 10. Hydroxyapatite was formed as per the following reaction: $8 \mathrm{HNO}$

$10 \mathrm{Ca}\left(\mathrm{NO}_{3}\right)_{2}+6\left(\mathrm{NH}_{4}\right)_{2} \mathrm{HPO}_{4}+2 \mathrm{H}_{2} \mathrm{O} \longrightarrow \mathrm{Cal}\left(\mathrm{PO}_{4}\right)_{6}(\mathrm{OH})_{2}+12 \mathrm{NH}_{4} \mathrm{NO}_{3}+$

The resulting suspension was boiled for 10 minutes and cooled in an ice bath overnight to obtain a white gelatinous precipitate. The pre-

*Corresponding authors: A. Singh, Lecturer, Department of Biotechnology, Lovely School of Sciences Lovely Professional University, Phagwara, India, Tel: +91-7837651937; E-mail: anjuvan@gmail.com

Received April 23, 2011; Accepted May 4, 2011; Published June 11, 2011

Citation: Singh A, Purohit KM (2010) Chemical Synthesis, Characterization and Bioactivity Evaluation of Hydroxyapatite Prepared from Garden snail (Helix aspersa). J Bioprocess Biotechniq 1:104 doi: 10.4172/2155-9821.1000104

Copyright: () 2010 Singh A, et al. This is an open-access article distributed under the terms of the Creative Commons Attribution License, which permits unrestricted use, distribution, and reproduction in any medium, provided the original author and source are credited. 
Citation: Singh A, Purohit KM (2010) Chemical Synthesis, Characterization and Bioactivity Evaluation of Hydroxyapatite Prepared from Garden snail (Helix aspersa). J Bioprocess Biotechniq 1:104 doi: 10.4172/2155-9821.1000104

cipitate was filtered and filtered cake (residue) was dried in the oven at $800 \mathrm{C}$. The dried sample of hydroxyapatite was ground to powder.

The thermal analysis of the Snail shell was performed by (NETZSCH-Geratebau GmbH Thermal Analyser) at a heating rate of $10^{\circ} \mathrm{C} /$ minutes from ambient to $1200^{\circ} \mathrm{C}$ to study the weight loss and thermal behavior. The powder samples of SS, calcined SS and synthesized HAP samples were examined with high resolution X-ray Diffractometer (PW-1830, Philips, Netherlands) using $\mathrm{Cu}-\mathrm{Ka}$ radiation. The $\mathrm{X}$-ray diffraction (XRD) patterns were recorded in the steps of $0.01^{\circ}$ interval with 1 s counting time at each step. Fourier transform infra red (FTIR) spectrum of synthesized HAP powder was obtained over the wave numbers $400-4500 \mathrm{~cm}^{-1}$. The powder was dispersed into pellets of $\mathrm{KBr}$ (mixed in 1:4 ratio) and the spectra was recorded with a PerkinElmer (S2000) IR spectrometer. The particle size analysis of HAP was done by Malvern Particle Size Analyzer (Model - Micro-P, UK). The surface morphology of SS and the prepared HAP powder were studied by Scanning Electron Microscope (SEM) while the surface area of the prepared HAP samples was determined with BET surface area analyzer (QUANTACHROME Model:Autosorb1).

\section{In vitro bioactivity evaluation}

The in vitro bioactivity evaluation of synthesized HAP powder from garden snail shell was performed in a stimulated body fluid (SBF) media of $\mathrm{pH} 7.4$ at a ratio of $1 \mathrm{mg} / \mathrm{ml}$ in a water bath at $37^{\circ} \mathrm{C}$. The changes in the $\mathrm{pH}$ of SBF medium were measured at pre-determined time intervals using a $\mathrm{pH}$ meter. Scanning electron microscopy (SEM) was used to identify the apatite formation on surface of the samples and to evaluate the surface morphology of the samples after immersion in SBF medium for 2, 8 and 15 days respectively.

\section{Preparation of (Synthetic Body Fluid) SBF}

SBF is known to be a metastable buffer solutions $[15,16]$ and even a small, undesired variance in both of the preparation steps and the storage temperatures, may drastically affect the phase purity and hightemperature stability of the produced HA powders, as well as the kinetics of the precipitation processes.

Merck-grade $\mathrm{NaCl}$ (99.5\%), $\mathrm{NaHCO}_{3}$ (99.5\%), $\mathrm{KCl}$ (99.0\%), $\left.\left.\mathrm{Na}_{2} \mathrm{HPO}_{4}\right) \cdot 2 \mathrm{H}_{2} \mathrm{O}(99.5 \%), \mathrm{MgCl}_{2}\right) \cdot 6 \mathrm{H}_{2} \mathrm{O}(99.0 \%), \mathrm{Na}_{2} \mathrm{SO}_{4},\left(\mathrm{CH}_{2} \mathrm{OH}\right)_{3} \mathrm{CNH}_{2}$ (99.5\%), $\mathrm{CaCl}_{2} \mathrm{H}_{2} \mathrm{O}(99.0 \%)$ and $\mathrm{HCl}(37 \mathrm{vol} \%$, Carlo-Erba, Rome, Italy) were used in the preparation of the SBF of this study.

SBF solutions [17-21] were prepared by dissolving appropriate quantities of the above chemicals in deionized water. Reagents were added, one by one after each reagent was completely dissolved in 700 $\mathrm{ml}$ of water, in the order given in Table 1 . A total of $40 \mathrm{ml}$ of $1 \mathrm{M} \mathrm{HCl}$ solution was consumed for $\mathrm{pH}$ adjustments during the preparation of 1 1 of SBF solutions. A $15 \mathrm{ml}$ aliquot of this acid solution was added just before the addition of the sixth reagent, viz., $\left(\mathrm{CaCl}_{2}\right) 2 \mathrm{H}_{2} \mathrm{O}$. Otherwise, the solution would display slight turbidity. The remaining part of the $\mathrm{HCl}$ solution was used during subsequent titration. Following the addition of the eight reagent (tris(hydroxymethyl) aminomethane), the solution temperature was raised from ambient to $37^{\circ} \mathrm{C}$. This solution was then titrated with $1 \mathrm{M} \mathrm{HCl}$ to a $\mathrm{pH}$ of 7.4 at $37^{\circ} \mathrm{C}$. During the titration process, the solution was also continuously diluted with consecutive additions of de-ionized water to make the final volume equal to 1 1. It was observed in this study that the prepared SBF solutions can be stored at $5^{\circ} \mathrm{C}$ for a month without degradation.

\section{Biodegradation Test}

Biodegradation test of calcined HAP prepared from garden snail shell (Helix aspersa) was done by taking Tris- $\mathrm{HCl}$ buffer solution. $0.05 \mathrm{MTris}-\mathrm{HCl}$ solution was prepared using distilled water. The $\mathrm{pH}$ of solution was maintained 7.4 at $37^{\circ} \mathrm{c}$ by adding $1 \mathrm{MHCl}$. Calcined HAP in the form of pallets were soaked in Tris- $\mathrm{HCl}$ buffer solution for one week then the samples were dried at $100^{\circ} \mathrm{c}$ and final weight loss of sample was determined by the formulae as given below:

$\%$ Weight Loss $=\frac{\mathrm{W}_{1}-\mathrm{W}_{2} \times 100}{\mathrm{~W}_{2}}$

where, $\mathrm{W}_{1}$ = initial weight of sample

$\mathrm{W}_{2}$ = final weight of sample after soaking in Tris- $\mathrm{HCl}$ solution.

\section{Results and Discussion}

\section{Dta/tga of snail shell (ss)}

Figure 1 Showed the DTA/TGA analysis of Snail Shell showed the weight loss at temperature between $90^{\circ} \mathrm{C}-120^{\circ} \mathrm{C}$ that is due to the physically adsorbed water. Over a wide range of temperature from $250^{\circ} \mathrm{C}-400^{\circ} \mathrm{C}$ the weight loss is due to the decomposition of $\mathrm{MgCO}_{3}$ combined with the combustion of hydrocarbons. The weight loss along with endothermic peak at $750^{\circ} \mathrm{C}-850^{\circ} \mathrm{C}$ indicates the decomposition of $\mathrm{CaCo}_{3}$ following the reaction.

$$
\mathrm{CaCO}_{3} \longrightarrow \mathrm{CaO}+\mathrm{CO}_{2} \uparrow
$$

So it is confirmed from the thermal analysis that Snail Shell mainly contains $\mathrm{CaCO}_{3}$ along with small amount of $\mathrm{MgCO}_{3}$ and other organic matters.

\section{XRD analysis}

A typical XRD profile of SS and calcined SS HAP has been shown in Figure 2. The raw SS showed the presence of $\mathrm{CaCO}_{3}$ phase, where as $\mathrm{CaO}$ was detected in the calcined Snail shell. The appearance of calcined SS was soft, porous and white in colour. However, due to delay in recording some amount of $\mathrm{CaO}$ was converted to $\mathrm{Ca}(\mathrm{OH})_{2}$ by adsorbing moisture from the atmosphere which is depicted in Figure $2 \mathrm{~b}$.

\begin{tabular}{|l|l|l|}
\hline Order & \multicolumn{1}{|c|}{ Reagent } & \multicolumn{1}{c|}{ Amount (gpl) } \\
\hline 1 & $\mathrm{NaCl}$ & 6.547 \\
\hline 2 & $\mathrm{NaHCO}$ & 2.268 \\
\hline 3 & $\mathrm{KCl}$ & 0.373 \\
\hline 4 & $\mathrm{Na}_{2} \mathrm{HPO}_{4} \cdot 2 \mathrm{H}_{2} \mathrm{O}$ & 0.178 \\
\hline 5 & $\mathrm{MgCl}_{2} \cdot 6 \mathrm{H}_{2} \mathrm{O}$ & 0.305 \\
\hline 6 & $\mathrm{CaCl}_{2} \cdot 2 \mathrm{H}_{2} \mathrm{O}$ & 0.368 \\
\hline 7 & $\mathrm{Na}_{2} \mathrm{SO}_{4}$ & 0.071 \\
\hline 8 & $\left(\mathrm{CH}_{2} \mathrm{OH}\right)_{3} \mathrm{CNH}_{2}$ & 6.057 \\
\hline
\end{tabular}

Patent pending. "Turkish Patent Institute," Turkey, Appl. No. 99-0037, 11 January (1999)

Table 1: Chemical composition of SBF solutions.

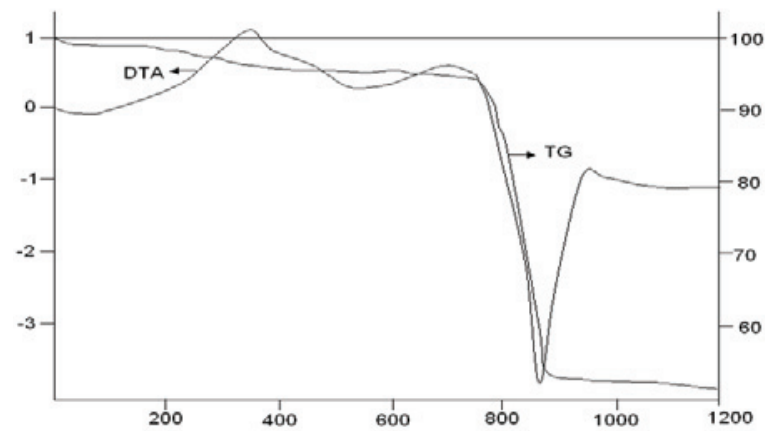

Figure1: Shows the TGA/DTA analysis of as dried Snail shell. 
Citation: Singh A, Purohit KM (2010) Chemical Synthesis, Characterization and Bioactivity Evaluation of Hydroxyapatite Prepared from Garden snail (Helix aspersa). J Bioprocess Biotechniq 1:104 doi: 10.4172/2155-9821.1000104

The XRD phase analysis of HAP powder has been shown in Figure 3. Three-high-intensity peaks located at $2 \theta=31.7^{\circ}, 32.2^{\circ}$ and $32.9^{\circ}$ with $\mathrm{Cu}-\mathrm{Ka}$ radiation are difficult to be exactly recognized from their diffraction patterns. XRD patterns reveals the formation of HAP and is well resembled with the standard JCPDS file. The unindexed peak at $30.75^{\circ}$ Figure $3 \mathrm{~b}$ may be due to $\beta$-tricalcium phosphate; which indicates the initiation of conversion of HAP to $\beta$-tricalcium phosphate on heating HAP above $800^{\circ} \mathrm{C}$. The calcined HAP exhibits well crystallized sharp peaks of characteristics HAP. The HAP powders, thus synthesized from Snail Shell precursor, are very pure and chemical analysis of powders confirms the same observation.

\section{FTIR analysis}

Infrared characterization was carried out for the sample to study the spectral characteristics indicative of the chemical bonding in the synthesized HAP powder. The spectrum Figure 4 can be divided into four regions with peaks having wave numbers around 3500, 1420, 1100 and $600 \mathrm{~cm}^{-1}$. The peak observed around $3431.8 \mathrm{~cm}^{-1}$ is due to the presence of $-\mathrm{OH}$ bond [22]. This peak is mainly due to $\mathrm{O}-\mathrm{H}$ stretching vibration in HAP [23]. The peak at $1036.2 \mathrm{~cm}^{-1}$ is associated with the stretching modes of the P-O bonds of HAP $[23,24]$. The double peak at $603.1 \mathrm{~cm}^{-1}$ and $567.4 \mathrm{~cm}^{-1}$ are due to bending modes of P-O bonds in phosphate groups [24]. Thus, the presence of $\mathrm{PO}_{4}^{3-}$ - group in HAP is almost confirm from IR studies. The $\mathrm{pH}$ of the medium during synthesis of HAP was maintained using ammonium solution and it was removed from the suspension with repeated washing with distilled water. In spite of all efforts to remove ammonia from the solution, there is a possibility of small amount of it in the HAP powder. The IR analysis shows a small broad peak at $1422.6 \mathrm{~cm}^{-1}$; which is characteristics peak of $\mathrm{NH}_{4}^{+}$- group [25-27].

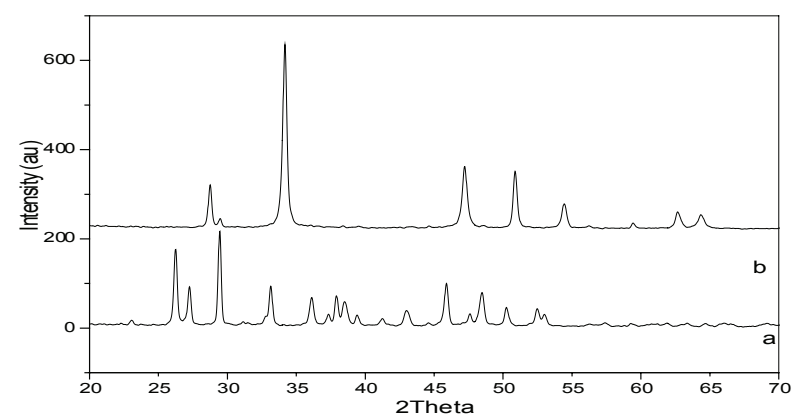

Figure 2: XRD patterns of (a), Snail shell; (b), Calcined snail shell at $1000^{\circ} \mathrm{C} / 2 \mathrm{Hr}$.

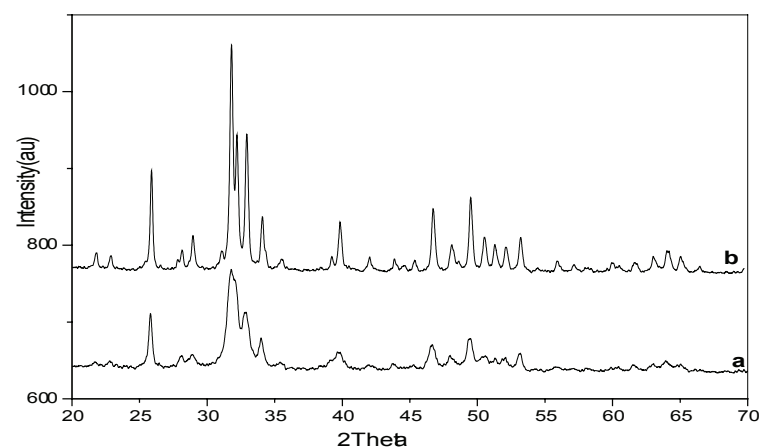

Figure 3: XRD Pattern of: (a) HAP(synthesized), (b) Calcined HAP (synthesized) $800^{\circ} \mathrm{C} / 2 \mathrm{Hr}$.

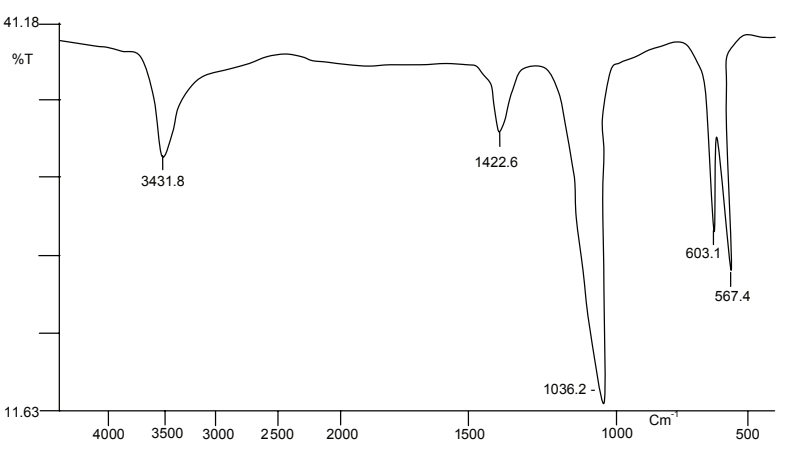

Figure 4: FTIR Spectrum of HAP powder.

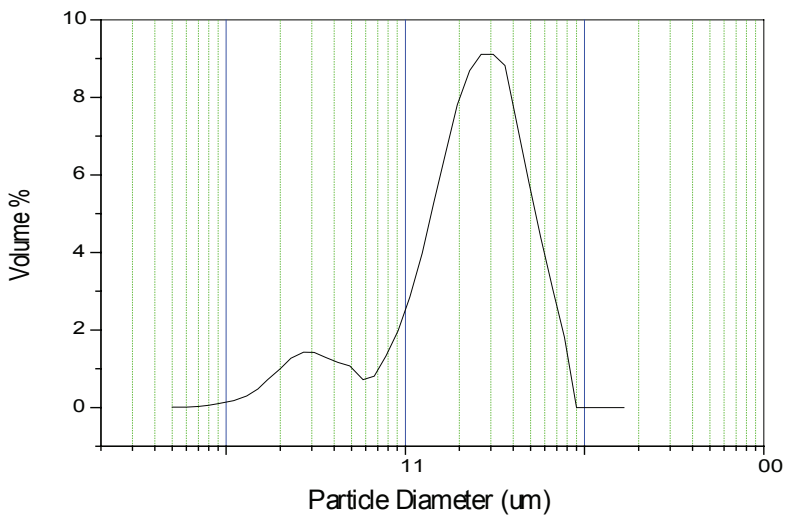

Figure 5: Particle Size Analysis of HAP powder.

(a)

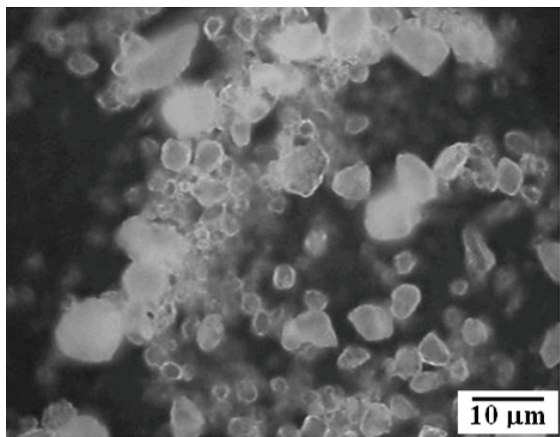

(b)

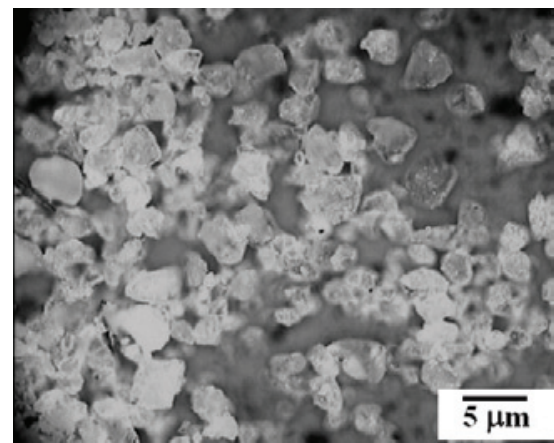

Figure 6: SEM Micrograph of (a) Synthesized HAP powder (b) Calcined $\left(850^{\circ} \mathrm{C} / 2 \mathrm{~h}\right)$ HAP powder. 
Citation: Singh A, Purohit KM (2010) Chemical Synthesis, Characterization and Bioactivity Evaluation of Hydroxyapatite Prepared from Garden snail (Helix aspersa). J Bioprocess Biotechniq 1:104 doi: 10.4172/2155-9821.1000104

Page 4 of 5

\section{Particle size analysis}

Particle size analysis of HAP powder was carried out following Laser technique and pattern of particle size distribution is plotted in Figure 5. Average particle size was found to be $2.63 \mu \mathrm{m}$. Small amount of fine particles $(0.2-0.3 \mu \mathrm{m})$ are also present in the synthesized powder.

\section{Surface area measurement}

The surface areas of the hydroxyapatite powder and calcined HAP are determined are 83 and $15 \mathrm{~m}^{2} / \mathrm{gm}$ respectively. Powders are agglomerated during calcinations; but HAP powders have to be calcined to remove volatile impurities like ammonia.

\section{Scanning electron microscope (SEM)}

The morphologies of as synthesized and calcined HAP powders are

(a)

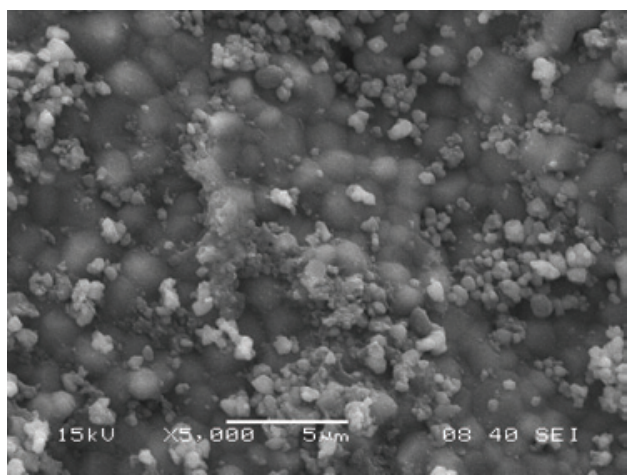

(b)

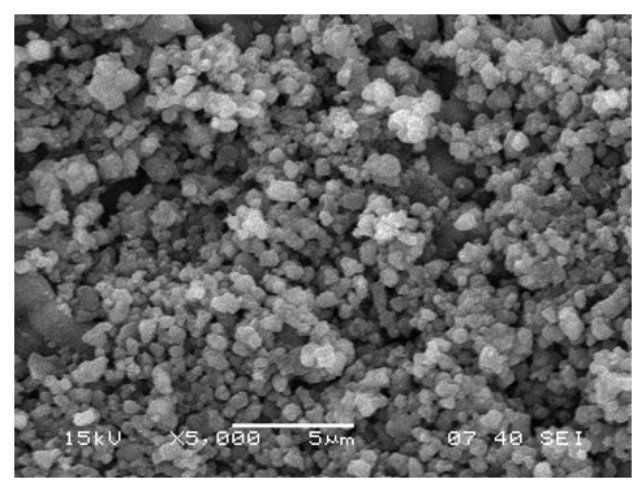

(c)

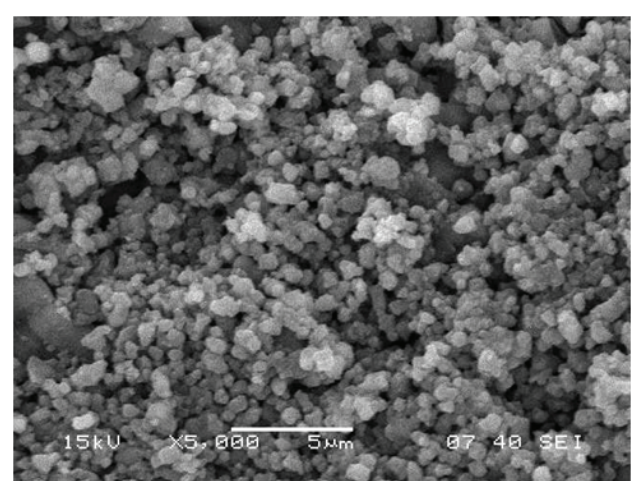

Figure 7: SEM micrographs of (a) the surfaces of synthesized HAP powders after soaking in SBF for 2 Days (b) the surfaces of synthesized HAP powders after soaking in SBF for 8 Days (c) the surfaces of synthesized HAP powders after soaking in SBF for 15 Days. shown in Figure 6. Uncalcined HAP powders are almost regular and round in shape; where as calcined HAP powders are agglomerated. The microstructure as reveals from SEM is in well- agreement with the particle size analysis and BET surface area analyzer results.

\section{Bioactivity evaluation}

The SEM micrographs of the surfaces of the immersed HAP powder after soaking in SBF for various periods of time are shown in Figure 7. Tiny agglomerated bone-like apatite particles could be formed on the surface of the HAP powders.

Figure 7 shows that tiny agglomerated bone-like apatite particles could be formed on the surface of the HA powders soaked for 2 days, 8 days and 15 days respectively. The number and the size of these agglomerated particles increased with increasing soaking times. Identification and evaluation of apatite formation on the surface of a material in SBF is useful for predicting the in vivo bone bioactivity of the material, not only qualitatively but also quantitatively [28-31]. The results indicated that the synthesized HAP powder from Garden Snail shell (Helix aspersa) showed the high bioactivity in SBF solution.

\section{In-vitro biodegradation}

Biodegradation of calcined HAP samples in the form of pallets were carried out in Tris- $\mathrm{HCl}$ solution. HAP samples were soaked in Trisbuffer solution at $\mathrm{pH} 7.4$ and temperature $37^{\circ} \mathrm{C}$ for 7 days [32]. When porous HA was soaked in Tris-buffer solution, the loss of calcium ion took place which resulted in the increase in $\mathrm{pH}$ of the buffer from 7.4 to 8.2 which confirms the biodegradation of HAP. The calcined HAP prepared from garden snail shell by chemical precipitation method showed weight loss of $4.5 \%$. Thus it appears that the ageing time in Tris- $\mathrm{HCl}$ solution may also affect the weight loss behavior.

\section{Conclusions}

A stoichiometric, pure and thermally stable hydroxyapatite powder was synthesized from Snail shell (Helix aspersa) by chemical precipitation method. XRD analysis indicated the phase purity and crystallinity of hydroxyapatite powder. TG/DTA result showed that Snail shell is mainly composed of calcium carbonate $\left(\mathrm{CaCO}_{3}\right)$. Fine particle size of hydroxyapatite was produced. The present work is based on the utilization of biological waste (Snail shell) to produce hydroxyapatite for Bio-medical applications. The prepared HAP powder showed high bioactivity similar to that in biological apatite and higher bioactivity in comparison with conventional HAP. Thus, prepared HAP from garden snail shell (Helix aspersa) might be more useful for treatment of oral bone defects in comparison with conventional HAP, and might be more effective as a bone replacement material to promote bone formation.

An attempt will be made in future to synthesize porous HAP and study its bio-compatibility. Mass production of biocompatible HAP for biological application may be possible at simple and low cost through this route.

\section{Acknowledgement}

The authors like to acknowledge H.O.D, Department of Chemistry, National Institute of Technology, Rourkela, for providing laboratory facilities for carrying out research work.

\section{Competing Interests}

The authors have no competing interests with the work presented in this manuscript. 
Citation: Singh A, Purohit KM (2010) Chemical Synthesis, Characterization and Bioactivity Evaluation of Hydroxyapatite Prepared from Garden snail (Helix aspersa). J Bioprocess Biotechniq 1:104 doi: 10.4172/2155-9821.1000104

Page 5 of 5

\section{References}

1. Layrotte P, Ito A and Tateishi T (1998) Sol-gel Synthesis of Amorphous Calcium Phosphate and Sintering into Microporous Hydrozyapatite Bioceramics. J. Am. Ceram. Soc 81: 1421-1428.

2. Li P, Ohtsuki C, Kokubo T, Nakanishi K, Soga N, et al. (1992) Apatite Formation Induced by Silica Gel in a Simulated Body Fluid. J. Am. Ceram. Soc 75: 2094-2097.

3. de Groot K (1900) Bioceramics Consisting of Calcium Phosphate Salts Biomaterials 1: 47-50

4. Jarcho M (1981) Calcium Phosphate Ceramics as Hard Tissue Prastetics. Clin Orthop Rel Res157: 259-278.

5. Brown PW, Fulmer M (1991) Kinetics of Hydroxyapatite Formation at Low Temperature. J. Am. Ceram. Soc 74: 934-940.

6. Young RA, Holcomb DW(1982) Variability of Hydroxyapatite Preparations. Calcified Tissue Int 34: 17-32.

7. Arita IH, Wilkinson DS, Mondragon MA, Castano VM (1995) Chemistry and Sintering Behaviour of Thin Hydroxyapatite Ceramics with Controlled Porosity Biomaterials 16: 403-408.

8. Brendel T, Engel A, Russel C (1992) Hydroxyapatite Coatings by Polymeric Route. J. Mater Sci: Mater. Med 3: 175-179.

9. Partenfelder UME, Engel A, Russel CA (1991) Pyrolutic Route for the Formation of Hydroxyapatite/Fluoroapatite Solid Solutions. J Mater. Sci: Mater. Med 4: 292-295

10. Roy DM, Linnehan SK (1974) Hydroxyapatite Formed From Coral Skeleta Carbonate by Hydrothermal Exchange Nature 247: 220-222.

11. Cowin SC, Vanburskirk WC, Ashaman RB (1987) Handbook of Bioengineering (eds) R Skalak and Schien C Newyork (McGRawHill)

12. Sinha A, Ingle A, Munim KR, Vaidya SN, Sharma BP, et al. (2001) Development of Calcium Phosphate based Bioceramics. Bull. Mater. Sci 24: 653-657.

13. Jarcho M (1978) Hydroxyapatite Ceramic U.S Patent, 4097935.

14. Liu C, Huang Y, Shen W, Cui J (2001) Kinetics of Hydroxyapatite Precipitation at $\mathrm{pH} 10$ to 11 . Biomaterials 22: 301-306.

15. Ohtsuki C, Kokubo T, Yamamuro T (1992) Mechanism of HA formation of $\mathrm{CaO}\left\{\mathrm{SiO}_{2}\right\} \mathrm{P}_{2} \mathrm{O}_{5}$ glasses in simulated body Fluid.J Non- Cryst Solids 143 : 84-92.

16. W Neuman, M Neuman (1958) The chemical dynamics of bone mineral Chicago University of Chicago Press p.34.

17. Li P, Kangasniemi I, de Groot K, Kokubo T (1994) Bone-like hydroxyapatite induction by a gel-derived titania on a titanium substrate. J Am Ceram So 77: 1307-12.

18. Li P, Nakanishi K, Kokubo T, de Groot K (1993) Induction and morphology of HA precipitated from metastable simulated body Fluids on sol gel prepared silica. Biomaterials 8: 963-8.

19. Li P,Kangasniemi I, de Groot K, Kokubo T, Yli-Urpo AU(1994) Apatite crystallization from metastable calcium phosphate solution on sol gel prepared silica. J Non-Cryst Solids 6: 281-286.

20. SO Cho, Nakanishi K, Kokubo T, Soga N, Ohtsuki C, et al. (1995) Dependence of apatite formation on silica gel on its structure: e!ect of heat treatment. J Am Ceram Soc 74: 1769-1774.

21. Kokubo T, Miyaji F, Kim HM, Nakamura T (1996) Spontaneous formation of bonelike apatite layer on chemically treated titanium metals. J Am Ceram Soc 9: 1127-1129.

22. Russell SW, Luptak KA, Suchicital CTA, Alford TLA, Pizziconi VB(1996) Chemical and Structural Evolution of Sol-Gel-Derived Hydroxyapatite Thin Films under Rapid Thermal Processing. J Am Ceram Soc 79: 837- 843

23. Sargin Y, Kizilyalli M, Telli C, Guler H (1997) A New Method for the SolidState Synthesis of Tetracalcium Phosphate: A Dental Cement: X-ray Powder Diffraction and IR Studies. J Eur Ceram Soc 17: 963-970.

24. Ramanan SR, Ramannan V (2004) A Study of Hydroxyapatite Fibers Prepared via Sol-Gel Route Material Letters 58: 3320-3323.

25. Tas Cuneyt (2000) Synthesis of Biomimetic Ca-Hydroxyapatite Powders at $37^{\circ} \mathrm{C}$ in Synthetic Body Fluids. Biomaterials 21: 1429-1438.

26. Caroline Victoria E, Gnanam FD (2002) Synthesis and Characterisation of Biphasic Calcium Phosphate Trends. Biomater Artif Organs 16: 12-14

27. Gomez-Morales J, Torrent-Burgues J, Boix T, Fraile J, Rodriguez-Clemen R (2001) Precipitation of Stoichiometric Hydroxyapatite by a Continuous Method. Cryst Res Technol 36: 15-16.

28. Williamson GK, Hall WH (1953) Acta Metall Sinica 1: 22

29. Hench LL, Wilson J (1993) An Introduction to Bioceramics 2nd ed. London: World Scientific Publishing Co Ltd

30. Murugan R, Ramakrishna S (2005) Aqueous mediated synthesis of bioresorbable nanocrystalline hydroxyapatite. J Cryst Growth 274: 209-213.

31. Kokubo T, Takadama $\mathrm{H}(2006)$ How useful is SBF in predicting in vivo bone bioactivity? Biomaterials 27: 2907-15

32. Soon-Ho Kwon, Youn-Ki Jun, Seong-Hyeon Hong, In-Seop Lee, Hyoun-Ee $\mathrm{Kim}$, et al. (2002) Calcium phosphate bioceramics with various porosities and dissolution rate. J Am Ceram Soc 85: 3129-31. 